denervated heart, of effects produced. by stimulation of distant sympathetic nerves, would seem to have led him to the verge of a discovery which O. Loewi was to make, just at this juncture, by a simpler and direct method. In Cannon's remaining active years he was largely concerned with evidence as to the nature of the sympathetic transmitter 'sympathin', which he believed to be not identical with adrenaline.

No mere account of Cannon's varied and uninterrupted contribution to the growth of physiological knowledge, over all these years, can give any adequate idea of the man, or of his stimulating influence on scientific research in his own country and widely beyond it. His character was drawn on large and simple lines; he was capable of deep and loyal friendships, and readily moved to sympathy and indignation by suffering and injustice. He was a man of sensitive conscience, full of the traditions and the ideals of his native land. He has himself attributed high importance to physical health as a factor of success in an investigator; and in his youth he must have had great strength and endurance. From middle life onwards, however, his health was marred by various allergies, and eventually by a slowly malignant condition, which he suspected to be an afteŕ-result of his early experiments with $\mathrm{X}$ rays, in the days before the potential dangers of these were known. His work, however, seemed to be little affected by conditions which must greatly have interfered with his bodily ease and broken his rest.

Cannon was early married to Cornelia James, who had been his schoolfellow. Apart from her own literary activities and social work, Mrs. Cannon shared intimately in her husband's interests, and their household, with a son and four daughters, was radiant with affection and quiet happiness. Cannon's last book, "The Wry of an Investigator", is a delightfully discursive talk on the life of research and on the genesis of scientific discovery. It has an autobiographical basis, and an intimate and ingenuous quality which allows a friend almost to hear the tone of Cannon's voice as he reads.

H. H. D.

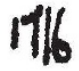

JoHN LoDIE BAND, a pioneer of television, died on June 14, at the age of fifty-eight, after an illness which gegan inf february, up to which time he had been aefvely phaged in research in various problems in television on the laboratories of his own company.

baird was the son of a Scottish minister and received his scientific education at the Royal Technical College, Glasgow, where he won an associate scholarship in electrical engineering. Experimental research had always been his hobby, and in the early days of his training he devised an improved pattern of selenium cell, which led him to develop a crude form of television.

When Baird was compelled by ill-health to abandon an active business career, he devoted himself exclusively to a study of the problem of television. He became a pioneer in this field in the early days of sound broadcasting, and was undoubtedly responsible for initiating public interest in this art.

The basic problem of television, as it was correctly appreciated by Baird, consists in the provision of means for scanning an image by subdividing it into tiny elements, transforming the resulting light variations into electrical impulses for transmission by line or radio to the receiver, where the impulses are reconverted back into light for the reconstruction of the picture. Some means for synchronizing the transmitter and receiver must also be provided. For the scanning process, Baird first used a revolving disk carrying a series of suitably placed lenses, and a synchronously driven disk at the receiving end. Very intense illumination was required on the subject to be televized, while the variation in the illumination obtained from a neon lamp was used to reproduce the picture at the receiving end. Working on these lines, Baird gave a demonstration of television on January 27,1926 ; this was claimed to be the first demonstration of true television ever witnessed. The original apparatus was afterwards exhibited in the Science Museum at South Kensington.

In the following years, many details of the system were improved and are described in a series of patent specifications. These covered such items as the means of illumination of the subject and even of the use of infra-red radiation to reduce the glare, which the subject found to be unpleasant; accurate methods of synchronizing transmitter and receiver; and an increase in the rapidity of scanning with a corresponding improvement in the definition of the reproduced pictures. Baird's demonstrations of the possibilities of television by radio led to the successful transmission of television across the Atlantic in February 1928, followed a few weeks later by experiments on board s.s. Berengaria while the receiving equipment was being brought back from New York.

The first step towards the inauguration of a television service in Great Britain was taken in 1929, when the B.B.C. decided to give Messrs. Baird Television, Ltd., facilities for experimental transmissions through the medium-wave London station. These transmissions, which were afterwards referred to as 'low-definition', employed 30 scanning lines and $12 \frac{1}{2}$ pictures per second, the programmes originating in the Baird studios in Long Acre, London. After about a year, these 30-line transmissions were considered to be of sufficient technical interest for the B.B.C. to equip a studio in Broadcasting House with Baird apparatus; and this was put into use in 1932. At this time the development of improved standards of definition was progressing rapidly, and several organisations were experimenting with systems using 120 lines.

In May 1934, the Postmaster-General appointed a committee to report on the relative merits of the several systems of 'high-definition' television, and to consider the conditions under which a public service might be provided using ultra-short waves to accommodate the large band-width necessary for the transmission of such systems. Among the Committee's recommendations was one to the effect that the first station should be in London, and that the two selected systems, Baird and Marconi-E.M.I., should each supply their own apparatus for alternative operation; the cost being borne by the revenue from the existing licence fee. Accordingly, towards the end of 1936, a public service was opened from Alexandra Palace, the two systems of transmission being used in alternate weeks. The Baird system provided 240 lines, 25 pictures per second with sequential scanning; whereas the MarconiE.M.I. system used 405 lines, and 25 pictures per second with interlaced scanning. After a few months' experience, the Television Advisory Committee recommended that the experimental period should be terminated, and that the standards to be adopted for the London station should be those provided by 
the Marconi-E.M.I. system, which is in use in the recently re-opened service from Alexandra Palace.

During all these years and until a few months before he died, Baird continued to work steadily towards the improvement of the scope and possibilities of television and its presentation. The system which bears his name had early taken advantage of the cathode ray tube for reception of the transmitted picture; and in December 1937 he demonstrated in London the optical projection of television pictures on to a cinema screen. The possibilities of introducing colour and stereoscopic effects had for many years also aroused his interest, and in 1944 he gave a demonstration of his recent achievements in the reception of television in colour by a method which avoided the need for revolving disks and lenses.

Altogether Baird played a notable part in stimulating the development of many aspects of television technique, and undoubtedly contributed materially towards the success attained by radio engineers and physicists, resulting in Britain being in the forefront of the world in this fascinating application of electromagnetic waves. $\quad$ R. L. SMrTH-Rose

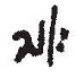

\section{Prof. Amadeus W. Grabau}

Amadeus W. GraAayras born of German stoek at Cedarburgh isconin, on January 9, 1870, his father and pderual grandfather being Lutheran Church pastoro. His grandparents had left Germany in the midde of last century to seek refuge in the United tates from persecution for refusal to conform to $0^{\circ}$ practices of the reformed Lutheran Church. Perhaps it was this ancestry which bred in Grabau that stubbornness and refusal to accept current geological dogma without challenge which characterized his career. His radical opinions, expressed with a forthrightness not always to the liking of more conservative minds, touched not only American and Asian geology, but also impinged forcibly on the fundamentals of world geology.

At the age of fifteen, Grabau was apprenticed to a bookbinder in Buffalo, N.Y., but he continued his education at evening classes, discovering the delights of botany and geology. His ability in a correspondence course in mineralogy led Prof. W. O. Crosby, of the Massachusetts Institute of Technology, to offer him in 1890 a post at the Boston Society of Natural History and a special studentship at the Institute. The young man now came into contact with a brilliant gathering of teachers and he responded readily to their influence. His interest in physiography was sharpened, but to it was added a lively knowledge of marine bionomies and, through Alpheus Hyatt and R. T. Jackson, of palæontology. He graduated in 1896, and entered Harvard University in 1897, where he took his master's (1898) and doctor's (1900) degrees. By way of Tuft's College, the Rensselaer Polytechnic Institute and the Geological Survey of Michigan, Grabau passed to a lectureship in palæontology at Columbia University in 1901, becoming full professor in 1905 .

Grabau had already published a number of studies on Pleistocene geology, such as "The Pre-Glacial Channel of the Genesee River" (his first paper) and on glacial phenomena of Cape Cod and of Glacial Lake Bouvé. But the richly fossiliferous Lower Palæozoic and Devonian rocks of New York State were an equal attraction, and he published papers on their faunas. In addition, he speculated (sometimes from unsound premises, as with the Fusidæ) on the phylogeny and bionomics of the fossil groupsDevonian fishes, Palæozoic corals and coral reefs, graptolites, gastropods, etc., all passed beneath his scrutiny. These essays were related to numerous others on the classification, nature and formation of sedimentary rocks and of salt deposits; for example, his book "Geology of the Non-Metallic Mineral Deposits other than Silicates. Vol. I. Principles of Salt Deposition" (1920). Grabau's widely ranging interests in stratigraphy, palæogeography, palæontology and sedimentation were, however, inter-related in his mind, and were synthesized into a whole in his "Principles of Stratigraphy" (1913). $\mathrm{He}$ stoutly advocated his views at meetings of the Geological Society of America, where his clashes with F. O. Ulrich and A. E. Foerste, who held other opinions equally strongly, became legendary. But the storms of the meeting-room were always followed by peace-making discussions afterwards.

The War of 1914-18 brought a crisis in Grabau's affairs. In an America where the teaching of German at public schools was banned and where streets and places with German names were re-christened, any defence of German literature, arts and science could not be tolerated. But Grabau commended these contributions to world culture, stubbornly refused to explain his views more fully, and ultimately left Columbia. China seized the opportunity and offered him the post of chief palæontologist to the National Geological Survey of China and professor of palæontology at the National University of Peking, which he accepted in 1920 .

Grabau plunged with vigour into his new tasks, and quickly built up a flourishing school at the University of Peking. The mass of palæontological material in the collections of the Survey was a mine he explored eagerly. The faunas of China were revealed, with adequate descriptions and figures, in a flood of monographs and papers by Grabau and by students he had trained. His own palæontological contributions were more particularly on the Palæozoic corals and brachiopods, though they embraced other groups from almost every age, and inevitably included discussions of their bionomics. The implications of this work on Chinese stratigraphy were quickly grasped by Grabau, and within four years of his arrival in that vast country he issued the first volume of his "Stratigraphy of China" (volume 2 came out in 1928), wherein he put forth new hypotheses to solve the difficult questions, while he later published a series of papers on "Problems in Chinese Stratigraphy". His "Permian of Mongolia", volume 4 of "Natural History of Central Asia", was the vehicle for a discussion of the Permian of the world, where his original ideas once more coloured a longdrawn-out debate. He held strong views on the migration of geosynclines, and in a number of papers on the pulsation theory strenuously advocated universal transgression and regression for a given geological period. His "Rhythm of the Ages", published in 1940, is characteristically stimulating and full of ideas.

The Geological Society of China honoured Grabau by founding the Grabau Gold Medal, of which he was the first recipient in 1925 , while later it celebrated his sixtieth birthday by dedicating volume 10 of its Bulletin to him. Its preface, signed by the eight leading Chinese geologists, is a moving testimony to the regard which he had won in his adopted country by the same inspiring enthusiasm, kindly under- 